\title{
Pengakuan Negara Baru Ditinjau Dari Perspektif Hukum Internasional (Studi terhadap kemerdekaan Kosovo)
}

\author{
Bayu Sujadmiko
}

Dosen Bagian Hukum Internasional FH Universitas Lampung

\begin{abstract}
Abstrak
Kosovo mendeklarasikan kemerdekaannya dari Serbia, di Pristina. Deklarasi dibaca Perdana Menteri Kosovo, Hashim Thaci, pada sidang parlemen yang dihadiri 109 anggota. Permasalahan kemerdekaan Kosovo tidak terlepas dari permasalahan politik dan etnis yang ada, namun apakah eksistensi Kosovo sebagai Negara baru ditentukan oleh keharusan adanya pengakuan dari Negara lain? dan apakah sikap PBB terhadap lahirnya Negara baru seperti Kosovo. Metode Penelitian yang digunakan adalah yuridis normatif yang dianalisis secara deskriftif. Hasil Penelitian menunjukkan bahwa pengakuan yang merupakan masalah politik dan tidak terlepas dari permasalahan hukum, terutama politik internasional namun tidak dapat disangkal bahwa tindakan pengakuan itu berakibat hukum, terutama dalam kaitan hubungan antara pihak yang mengakui dan pihak yang diakui. Selain itu, ada tidaknya pengakuan terhadap negara baru tidak berpengaruh terhadap eksistensi negara baru tersebut, termasuk pengakuan dari $P B B$.
\end{abstract}

\section{Kata Kunci: Kemerdekaan Kosovo, Pengakuan Negara, Eksistensi}

\section{Pendahuluan}

Pada tanggal 17 Februari 2008, parlemen Kosovo telah membuat sejarah, yaitu memproklamasikan Kosovo sebagai negara merdeka, yang lepas dari Serbia ${ }^{1}$. Kosovo mendeklarasikan kemerdekaannya dari Serbia, Minggu, di ibukota, Pristina. Deklarasi itu dibacakan oleh Perdana Menteri Kosovo, Hashim Thaci, pada sidang parlemen yang dihadiri 109 anggota. Sebelumnya Kosovo adalah satu provinsi dibawah kekuasaan Serbia yang mayoritas beretnis Albania. Kosovo pada 16 tahun yang lalu (tahun 1992) sudah

\footnotetext{
${ }^{1}$ http://www.detiknews.com/read/2008/09/2 0/ 104308/1009385/10/pelopor-klaimsepihak-hak-kemerdekaan.
}

pernah menyatakan merdeka, namun hanya Albania yang mengakui kemerdekaan itu ${ }^{2}$. Kemerdekaan waktu itu seperti tidak berarti apaapa karena dianggap hanya pemberontakan biasa dan kemudian Kosovo didera konflik etnis yang berkepanjangan dan perang melawan Serbia selama tiga tahun antara tahun 1996-1999. Kosovo kemudian berada di bawah pengawasan Dewan Keamanan Perserikatan Bangsa Bangsa (DK PBB). Melalui Resolusi DK PBB No. 1244 Kosovo mendapatkan status provinsi otonom. Dengan dukungan Amerika Serikat, ${ }^{3}$ secara sepihak Kosovo telah menyatakan merdeka dan sehari kemudian telah mendapatkan

\footnotetext{
${ }^{2}$ http://agguss.wordpress.com/tag/kosovo/

${ }^{3}$ www.konsultasi.wordpress.com
} 
pengakuan dari Norwegia, Denmark, Finlandia, Swedia, Jerman, Italia, Perancis, Inggris, Austria Albania, Turki, dan Afganistan. Sementara yang menentang atau menolak mengakui adalah Serbia, Rusia, Spanyol, Rumania, Slowakia dan Cyprus. Bahkan Serbia menarik seluruh diplomat dari Negara-negara yang mengakui kemerdekaan Kosovo.

Sementara itu, PBB sendiri belum memberikan pengakuan resmi kepada Kosovo, bahkan Serbia dan Rusia meminta Dewan Keamanan PBB untuk segera bersidang membahas Deklarasi sepihak oleh parlemen Kosovo tersebut. Dalam beberapa sidang Dewan Keamanan PBB, Rusia sebagai salah satu anggotanya selalu saja memveto untuk tidak memberikan kemerdekaan kepada Kosovo. ${ }^{4}$

Permasalahan kemerdekaan Kosovo ini memang tidak terlepas dari permasalahan politik dan etnis yang ada, namun apakah eksistensi Kosovo sebagai Negara baru ditentukan oleh keharusan adanya pengakuan dari Negara lain? dan apakah sikap PBB terhadap lahirnya Negara baru seperti Kosovo?

\section{Pengertian Pengakuan}

Sebagaimana dikatakan oleh pakar Hukum Internasional Amerika Serikat, MOORE, maka pengakuan berguna untuk menjamin bahwa suatu Negara baru dapat menduduki tempatnya yang wajar sebagai suatu organisme politik yang merdeka dan berdaulat ditengah keluarga bangsabangsa sehingga ia dapat

4

http://www.detiknews.com/read/2008/09/20/ 104308/1009385/10/pelopor-klaim-sepihakhak-kemerdekaan mengadakan berbagai hubungan dengan negara-negara lain secara aman dan sempurna, tanpa khawatir kedudukanya sebagai kesatuan politik itu akan diganggu oleh negara-negara yang telah ada. ${ }^{5}$

Sementara itu pengakuan ialah perbuatan politik dimana suatu Negara menunjukan kesediaannya untuk mengakui suatu situasi fakta dan menerima akibat hukum dari pengakuan tersebut. ${ }^{6}$ Kemudian dalam praktek Negara modern pengakuan bukan sekedar mengetahui (cognition) ${ }^{7}$, atau lebih daripada suatu pernyataan mengetahui bahwa suatu negara atau pemerintah memenuhi syarat untuk diakui. Hal ini dibuktikan dengan fakta, antara lain bahwa mungkin saja terjadi penundaan sebelum suatu Negara atau pemerintah diakui, meskipun status Negara atau pemerintah itu tidak diperlukan lagi. Tujuan praktis pengakuan ialah diawalinya hubungan resmi dengan Negara-negara lain yang mengakui. Sekali pengakuan itu diberikan, maka tindakan itu berarti menghilangkan kemungkinan negara yang mengakui untuk mempersoalkan kembali syaratsyarat untuk diakuinya negara atau pemerintah terkait.

Sebagai tambahan tentang bentuk pengakuan tadi, masih terdapat pengakuan terhadap suatu Negara seperti, pemberontak, organisasi pembebasan bangsa,

\footnotetext{
${ }^{5}$ Setyo Widagdo, Masalah-Masalah Hukum Internasional Publik, Bayu Media Publishing, Malang 2008, hal.220

6 Boer Mauna, Hukum Internasional, Pengertian Peranan dan Fungsi dalam Era Dinamika Global, Alumni, Bandung 2000, hal 60 .

7 J.G. Starke, Pengantar Hukum Internasional, Edisi Kesepuluh, Sinar Grafika, Jakarta 2004, hal 177
} 
pengakuan atas wilayah, traktat baru dan lain-lain. ada juga pengakuan yang diberikan secara terang-erangan dan secara diam-diam ${ }^{8}$, dan terakhir adalah pengakuan secara de jure dan de facto .

\section{Teori-Teori tentang Pengakuan}

Dalam literatur-literatur hukum Internasional maupun hukum tata Negara, secara garis besar dapat ditemukan dua teori terkenal mengenai pengakuan yaitu teori konstitutif dan teori deklaratif.

\section{a. Teori Konstitutif}

Menurut pendukung teori konstitutif berpandangan bahwa suatu negara dianggap lahir sebagai negara baru jika telah diakui oleh negara lain, artinya sebuah negara belum dianggap ada sebagai Negara baru sebelum adanya pengakuan dari Negara lain. Dengan demikian pengakuan semacam itu memiliki kekuatan konstitutif. $^{10}$ Brownlie mengatakan "Constitutivist doctrine creates a great many difficulties" 11

Dalam artian bahwa apa yang dikatakan oleh pendukung teori konstitutif hanya menciptakan banyak kesulitan, jika teori tersebut diterapkan. Bahkan teori tersebut semakin tidak populer ketika pasal 3 Deklarasi Montevideo tahun 1933 tentang Hak-Hak dan Kewajiban Negara menyebutkan bahwa keberadan politik suatu Negara bebas

8 John O'Brien, International law, Cavendish, London 2001, hal 170

9 I.A. Shearer, Starke's International Law, Butterworth, London 1994, hal 118

${ }^{10}$ Malcom N. Shawn., International Law, $2^{\text {nd }}$.ed., Grotius Publication Limited, Cambridge 1986, hal 208.

11 Ian Brownlie, Principles of Public International Law, $3^{\text {rd }}$.ed., Oxford University Press, New York 1979, hal 93 dari pengakuan oleh Negara-negara lain.

Pendukung utama teori ini ialah Prof. Lauterpacht yang menyatakan bahwa "a state is, and becomes, an international person through recognition only and exclusively", selanjutnya ditegaskan pula bahwa "Statehood alone does not imply membership of the family of nations", untuk menguatkan sifat hukum dari perbuatan pengakuan, ia juga menegaskan bahwa "recognition is a quasi judicial duty and not an act of arbitrary discreation or a political concession". 12

\section{b. Teori Deklaratif}

Pengakuan tidak menciptakan suatu Negara karena lahirnya suatu Negara semata-mata merupakan suatu fakta murni dan dalam hal ini pengakuan hanya penerimaan fakta tersebut. Mereka menegaskan bahwa suatu Negara begitu lahir langsung menjadi anggota masyarakat internasional dan pengakuan hanya merupakan pengukuhan dari kelahiran tersebut, jadi pengakuan tidak menciptakan suatu Negara. Pengakuan bukan merupakan syarat bagi kelahiran suatu Negara. ${ }^{13}$

Menurut teori deklaratif ini pengakuan hanya merupakan pernyataan atau pengesahan saja (to declare) dari Negara yang memberikan pengakuan bahwa suatu Negara baru tersebut telah ada dalam pergaulan masyarakat internasional, asalkan secara objektif sudah memenuhi kualifikasi internasional dengan sendirinya sudah dapat diterima sebagai pribadi

12 L. Oppenheim, International Law, A Treaties, $8^{\text {th }} . e d .$, Longman, London 1955 , hal 125-127

${ }^{13}$ Boer Mauna, Op.cit., hal 62 
internasional

(international

personality) terlepas dari ada atau tidaknya Negara yang mengakui. Dengan demikian, Negara baru tersebut sudah dapat menikmati hakhak dan melaksanakan kewajibankewajibannya menurut hukum internasional, seperti Negara-negara lainya. ${ }^{14}$

Teori deklaratif menetralisisasi eksistensi suatu Negara dari masalah pengakuan yang nyata-nyata sangat subjektif itu. Teori deklaratif ini dapat dikatakan lebih objektif dan netral daripada teori konstitusif yang dalam prakteknya sudah ditinggalkan karena eksistensi suatu negara tidak ditentukan oleh ada atau tidak adanya pengakuan Negara-negara lain. $^{15}$

Ada beberapa kasus yang mencerminkan teori declaratory ini, salah satunya yang terdapat dalam Arbitrase Tinocco 1923. Dalam putusanya Arbitrator menyatakan bahwa pemerintahan Tinocco di Kosta Rika tidak diakui oleh inggris, namun tetap merupakan pemerintahan yang sah, sebagaiman dikutip dari keputusan arbitrase yang berbunyi: ${ }^{16}$

1. The rule that if a question arises in the courts of a new State as to the date at which the State came to existence, it will be irrelevant to consider the date when treaties with other States recognizing it came into operation. The date when the requirements of statehood were in fact first fulfilled is the only material date.

\footnotetext{
14 Wayan Parthiana, Pengantar Hukum Internasional, Mandar Maju, Bandung 1990, hal 350

${ }^{15}$ Setyo Widagdo, Op.cit, hal 224

${ }^{16}$ David J.Harris, Cases and Materials on International Law, Sweet and Maxwell, London 1983, hal 132-4
}

2. The rule that recognition of $a$ new State has retroactive effect, dating back to its actual inception as an independent state $^{17}$

Sebagaimana diketahui salah satu ciri pokok hubungan internasional sesudah tahun 1945 adalah menjamurnya Negara-negara baru setelah membebaskan diri dari kekuasaan colonial. Sehubungan dengan itu, hukum internasional tidak melarang gerakan-gerakan pembebasan nasional untuk menentang kekuasaan penjajah dan bahkan mendorongnya seperti terdapat dalam dokumen PBB terutama Resolusi $1514(\mathrm{XV}) .{ }^{18}$ Era bagian kedua abad ke-20 adalah era dekolonisasi yang merombak komposisi masyarakat bangsabangsa sebelumnya dan yang sekaligus merombak persyaratan untuk menjadi anggota masyarakat Internasional.

Uraian tersebut menegaskan bahwa kelahiran suatu Negara adalah suatu peristiwa yang tidak berkaitan langsung dengan hukum internasional, sedangkan pengakuan yang diberikan kepada Negara yang baru lahir hanya bersifat politik, semacam pengukuhan terhadap statusnya sebagai anggota masyarakat internasional yang baru dengan segala hak dan kewajiban yang dimilikinya sesuai dengan hukum internasional.

Berdasarkan kedua teori diatas ada beberapa pendapat para ahli hukum internasional yang memaparkan beberapa bentukbentuk pengakuan yang dilakukan oleh negara-negara terhadap lahirnya Negara baru:

\footnotetext{
${ }^{17}$ I.A. Shearer, Op.cit, hal 121

${ }^{18}$ Boer Mauna, Op.cit, hal 64
} 
a. Pengakuan de facto dan de jure

b. Pengakuan secara diam-diam (Implied Recognition)

c. Pengakuan Kolektif

d. Pengakuan Prematur

e. Pengakuan terhadap Pemberontak (Insurgency and Belligerency)

f. Pengakuan Bersyarat

g. Pengakuan terhadap Pemerintahan dan Demokrasi

Beberapa bentuk pengakuan diatas adalah realisasi dari kedua teori mengenai pengakuan terhadap lahirnya Negara baru. ${ }^{19}$

\section{Pengakuan Terhadap Lahirnya Negara Baru}

Pada Umumnya para pakar hukum Internasional sependapat bahwa pengakuan (recognition) ialah suatu lembaga yang teramat penting artinya dalam hubungan internasional. Apa lagi dalam masa globalisasi seperti ini, tampak sekali bahwa tidak ada satu negara pun yang dapat hidup terisolasi atau terasing dari negara-negara lainnya, dan berbagai media tekhnologi modern telah mendorong untuk mengembangkan hubungan antara negara-negara di dunia ini. Namun sebelum negara baru dapat mengadakan hubungan atau komunikasi yang lengkap dan sempurna dalam berbagai bidang dengan negara-negara lain, baik politis, ekonomi, sosial budaya, ilmu pengetahuan dan tekhnologi, terlebih dahulu negara itu harus melalui pintu pengakuan $^{20}$.

19 Jawahir Thontowi., Pranoto Iskandar., Hukum Internasional Kontemporer, PT. Refika Aditama, Bandung 2006, hal 134-142

${ }^{20}$ Ian Brownlie, Op.cit, hal 60-72
Pengakuan dalam hukum internasional merupakan persoalan yang cukup rumit karena sekaligus melibatkan masalah hukum dan politik. Dalam masalah pengakuan, unsur-unsur politik dan hukum sulit untuk dipisahkan secara jelas karena pemberian dan penolakan pengakuan oleh suatu negara sering dipengaruhi pertimbangan politik, sedangkan akibatnya mempunyai ikatan hukum. Kesulitan juga berasal dari fakta bahwa hukum internasional juga tidak mengharuskan suatu negara untuk mengakui negara lain atau pemerintah lain seperti juga halnya bahwa suatu negara atau suatu pemerintah tidak mempunyai hak untuk diakui oleh negara lain. Tidak ada keharusan untuk mengakui seperti juga tidak ada kewajiban untuk tidak mengakui. ${ }^{21}$ Seperti dikemukakan Komisi Arbitrase, Konfrensi Perdamaian mengenai Yugoslavia, pengakuan merupakan suatu perbuatan berhati-hati yang dapat dilakukan negara disaat yang dikehendaki dan dalam bentuk yang ditentukanya secara bebas. ${ }^{22}$

Moore dalam tulisannya yang termuat dalam Digest of International Law, Vol 1, disebutkan bahwa suatu jaminan yang telah diberikan kepada suatu Negara baru bahwa ia akan diperkenankan mengambil tempat atau tingkatan yang layak dalam karakteristiknya

21 Nguyen Quoc, Dinh, Patrick Daillier, Alain Peller, Droit International Public, $5^{\text {th }}$.ed, Libraire Generale de Droit et de Jurisprudence, Paris 1994, hal 34

${ }^{22}$ Avis de la Commission d'arbitrage de la Conference de la Paix la Yugoslavia, avis No. 10, du 4 Juillet 1992, p 4., Kutip Boer Mauna, Op.cit, hal 59 
sebagai suatu orgnisasi politik dalam masyarakat bangsa-bangsa ${ }^{23}$.

Namun dalam perkembanganya sampai saat ini masih ada dua golongan dari pakarpakar hukum internasional yang berbeda pendapat mengenai suatu pengakuan Negara. ${ }^{24}$ Golongan pertama berpendapat bahwa apabila semua unsur kenegaraan (ada rakyat, ada wilayah dan ada pemerintahan yang berdaulat dan ada kemamapuan dalam melakukan hubungan dengan Negara lain ${ }^{25}$ ) telah dipenuhi oleh masyarakat politik, maka dengan sendirinya ia telah merupakan sebuah Negara dan harus diperlakukan secara demikian oleh Negara-negara lainya. Golongan pertama ini disebut sebagai penganut teori deklatoir (declaratory theory). Golongan kedua menyatakan bahwa walaupun unsur kenegaraan telah terpenuhi oleh suatu masyarakat politik, namun tidaklah ia secara otomatis dia dapat diterima sebagai Negara ditengah-tengah masyarakat internasional . Terlebih dahulu harus ada pernyataan dari Negara-negara lain, bahwa masyarakat politik telah memenuhi persyaratan sebagai Negara. ${ }^{26}$ Kemudian barulah ia dapat menikmati haknya sebagai Negara baru. Golongan kedua Ini disebut penganut teori Konstitutif (constitutive theory).

Untuk mengakui Suatu Negara baru pada umumnya Negaranegara memakai kriteria, antara lain sebagai berikut;

${ }^{23}$ Syahmin . A.K., Hukum Internasional Publik dalam Kerangka Studi Analitis 2, Binacipta, Bandung 1992, hal 298

${ }^{24}$ Tasrif. S., Pengakuan Internasional dalam Teori dan Praktek, PT. Media Raya, Jakarta 1966 hal 34

${ }^{25}$ J.L. Brierly, The Law Nations, $5^{\text {th }}$.ed, Clarendon Press, Oxford 1955

${ }^{26}$ Syahmin . A.K., Op.cit., hal 301
1. Keyakinan adanya stabilitas di Negara tersebut

2. Dukungan umum dari Masyarakat atau Penduduk

3. Kesanggupan dan kemauan untuk melaksanakan kewajibankewajiban Internasional. ${ }^{27}$

Dalam kaitanya dengan itu, Ivan Shearer menyatakan bahwa pengakuan yang akan diberikan oleh Negara-negara dihadapkan pada dilema dan pada umumnya disebabkan oleh dua alasan. Pengakuan lebih terkait dengan kebijakan dibanding persoalan hukum, sebagaimana yang terlihat dalam praktek Negara-negara. Kebijakan Negara yang memberikan pengakuan didasarkan pada pertimbangan-pertimbangan yang terkait dengan menjaga kepentinganya sendiri. Dalam hal pemberian pengakuan terdapat pertimbangan politis seperti persoalan perdagangan yang sangat mempengaruhi proses pengakuan. Selanjutnya, terdapat sebuah kecenderungan dalam praktek bahwa pemberian pengakuan dengan mendasarkan pada prinsip-prinsip hukum, tidak lebih sebagai kedok bagi sebuah keputusan politik. ${ }^{28}$

Lahirnya sebuah Negara baru dapat melalui bermacam cara, seperti melepaskan diri dari penjajah bagi bekas wilayah jajahan, pemisahan diri sebagian wilayah suatu Negara dan berdiri sendiri sebagai sebuah Negara merdeka, atau pecahnya sebuah Negara menjadi beberapa

\footnotetext{
27 Myres S. Mc. Dongal, W. Michael Reisman, International Law in Contemporary Perspective, The Foundation Press, Inc, Mineola, New York 1981, hal 318

28 Jawahir Thontowi., Pranoto Iskandar., Op.cit, hal 132
} 
Negara yang lebih kecil daripada Negara semula, maupun penggabungan beberapa Negara menjadi sebuah Negara yang baru sama sekali. ${ }^{29}$

Kemerdekaan Kosovo dapat digolongkan sebagai lahirnya Negara baru jenis kedua, yaitu pemisahan diri sebagian wilayah suatu Negara dan berdiri sendiri sebagai sebuah Negara merdeka karena sebelumnya Kosovo adalah salah satu provinsi dari Serbia. Kelahiran Negara baru seperti Kosovo, dalam masyarakat internasional akan menimbulkan reaksi dari Negara-negara lain yang dimanifestasikan dalam pernyataan sikap menerima atau mengakui kelahiran Negara baru tersebut atau sebaliknya ada negara yang menolak atau tidak mengakui kehadiran Negara baru tersebut. Pengakuan dalam hukum internasional merupakan persoalan yang cukup rumit karena sekaligus melibatkan masalah hukum dan masalah politik. Dalam masalah pengakuan, unsurunsur politik dan hukum sulit untuk dipisahkan secara jelas, karena pemberian dan penolakan pengakuan oleh suatu Negara sering dipengaruhi oleh pertimbangan politik, sedangkan akibatnya mempunyai ikatan hukum. $^{30}$ Hal ini senada dengan apa yang dinyatakan oleh O'Connel "Recognition is a political act with legal consequences". 31

\section{Permasalahan}

apakah pengakuan masuk wilayah hukum atau masalah politik dapat dikembalikan kepada persoalan apakah lahirnya suatu Negara merupakan peristiwa hukum atau peristiwa politik. Ada dua pendapat

\footnotetext{
${ }^{29}$ Wayan Parthiana, Op.cit, hal 347

${ }^{30}$ Boer Mauna, Op.cit, hal 59

${ }^{31}$ O'Connel, International Law for Students, Steven \& Sons, London 1971, hal 49
}

mengenai persoalan tersebut, pertama menyatakan bahwa lahirnya suatu Negara hanya merupakan suatu peristiwa fakta yang sama sekali lepas dari ketentuan hukum internasional. Kelahiran Negara hanya merupakan fakta politis. ${ }^{32}$ Sementara pendapat kedua menyatakan lahirnya sebuah Negara merupakan suatu proses hukum yang diatur oleh ketentuan-ketentuan hukum Internasional. ${ }^{33}$

Diantara kedua pendapat tersebut, tampaknya pendapat pertama yang dianut oleh para ahli hukum yang menyatakan bahwa kelahiran suatu Negara bukan merupakan peristiwa hukum. Tidak mungkin hukum internasional mengatur lahirnya suatu Negara, karena Negara hukum itu ada atau lahir setelah adanya Negara-negara. Negara-negara merdekalah yang merumuskan hukum internasional dan bagi Negara-negara tersebut pulalah hukum itu berlaku. Bagi Negara-negara yang belum merdeka dan yang masih dibawah kekuasaan asing, tentu saja hukum internasional belum dapat diberlakukan. Jadi lahirnya suatu Negara tidak mungkin diatur oleh ketentuan-ketentuan hukum internasional sehingga kelahiran tersebut tidak dapat dikatakan sebagai proses hukum.

Pengakuan terhadap Negara baru lebih sering dan lebih banyak didasarkan kepada pertimbanganpertimbangan politik subjektif dari pihak dari pihak yang ingin memberikan pengakuan. Hal ini dapat kita lihat pada kasus lahirnya Kosovo, ketika parlemen mendeklarasikan kemerdekaanya, sehari kemudian Negara-negara yang selama ini satu haluan politik, satu

\footnotetext{
${ }^{32}$ Boer Mauna, Op.cit, hal 61

${ }^{33}$ Setyo Widagdo, Op.cit, hal 222
} 
ideologi dengan Kosovo langsung memberikan pengakuan, dan sebaliknya Negara-negara yang bermusuhan tidak satu ideologinya dan berbeda haluan politiknya menolak memberi pengakuan. Jika dianut bahwa lahirnya suatu Negara hanya merupakan peristiwa fakta dan bukan peristiwa hukum maka akibatnya adalah tidak mungkin suatu Negara menolak lahirnya Negara baru dengan alasan hukum. Akibat lain adalah lahirnya suatu Negara bebas dari pengakuan, dengan kata lain pengakuan tidak ikut campur pembentukan Negara. Artinya, eksistensi suatu Negara yang baru lahir tidak ditentukan keharusan adanya pemberian atau penolakan pengakuan dari Negara lain. Hal itu juga berlaku bagi Kosovo, jadi jelas bahwa pengakuan adalah suatu kebijaksanaan politik. ${ }^{34}$

Suatu Negara atau kelompok Negara mengakui atau tidak mengakui suatu Negara lain sematamata didasarkan atas pertimbangan politik dari Negara atau kelompok Negara yang bersangkutan. Mengenai hal tersebut, Amerika Serikat menunjukan sikap yang jelas dengan menyatakan "In the view of United States, International does not require a state to recognize another entity as a state; it is a matter for judgment of each state whether an entity merits recognitions as a state". ${ }^{35}$

\section{Lahirnya Kosovo Sebagai Negara Baru}

Diawal tulisan ini telah
dipaparkan bahwa tanggal 17

\footnotetext{
${ }^{34}$ Setyo Widagdo, Op.cit, hal 223

${ }^{35}$ Gerhard Von Glahn, Law Among Nations, $4^{\text {th }}$. ed. Mac Millan Publishing Inc, New York 1981, hal 93
}

Februari 2008 yang lalu parlemen Kosovo mendeklarasikan kemerdekaan provinsi Kosovo sebagai sebuah negara baru yang merdeka dan berdaulat. Artinya, Kosovo telah memisahkan diri dari Serbia secara sepihak. Situasi tersebut, dimungkinkan karena selain Kosovo mendapatkan dukungan Amerika Serikat juga karena konflik etnis yang berkepanjangan dan penindasan serta ketidakadilan selama ini memicu munculnya deklarasi kemerdekaan.

Masalahnya, apakah Kosovo sah menjadi sebuah negara baru? Haruskah ada pengakuan dari negara lain atas keberadaanya? Bagaimana dengan belum adanya pengakuan dari PBB? dan masalah lain yang mungkin timbul.

Apabila melihat uraian yang telah dikemukakan sebelumnya, sesungguhnya kelahiran kosovo sebagai negara baru dapat dikatakan sah karena telah memenuhi kualifikasi yang melekat pada diri kosovo sebagai negara baru. Yakni ada penduduk, memliki wilayah, mempunyai pemerintahan dan memiliki kemampuan untuk melakukan hubungan dengan negara lain. Hal ini sesuai dengan apa yang dikemukakan oleh Boer bahwa lahirnya suatu negara hanya merupakan suatu peristiwa fakta yang sama sekali lepas dari ketetuanketentuan hukum internasional, meskipun demikian hendaknya kita harus membedakan antara negara sebagai pribadi internasional pada satu sisi dengan kemampuan negara baru itu sebagai pribadi internasional dalam melaksanakan kewajibankewajiban internasionalnya pada sisi yang lain.

Suatu negara baru untuk dapat dikatakan memiliki pribadi 
internasional atau sebagai negara baru memang tidak membutuhkan pengakuan dari negara-negara lain sesuai pandangan teori deklaratif. Akan tetapi sebagai pribadi internasional yang membutuhkan hubungan dengan negara lain subjek hukum internasional lainya, negar baru itu membutuhkan pengakuan dari negara-negara lain karena dengan pengakuan tersebut, negara baru itu dapat mulai mengadakan hubungan yang akan melahirkan hak-hak dan kewajiban-kewajiban internasional yang harus dilaksanakan dalam pergaulan internasional. Itulah yang disebut jalan tengah untuk menjembatani antara teori deklaratif dan konstitutif. $^{36}$

Setelah

Proklamasi

Kemerdeka-an Kosovo, sudah banyak negara-negara lain yang mendukung Kosovo sekaligus mengakui dan mungkin saja ada negara-negara lain yang secara diamdiam melakukan tindakan-tindakan yang mencerminkan pengakuan terhadap keberadaan Kosovo, misalnya membuka hubungan diplomatik, menandatangani perjanjian dengan Kosovo atau kepala negara/kepala pemerintahan negara lain tersebut secara resmi mengadakan kunjungan kenegaraan kepada Kosovo. Namun semua itu bukan syarat atau keharusan bagi keberadaan Kosovo sebagai negara baru, tetapi hanya memperkuat fakta bahwa kosovo telah lahir dan ada yang menghormati Kosovo sebagai negara yang utuh.

Bagaimana dengan belum adanya pengakuan dari PBB? Sejarah telah membuktikan bahwa salah satu ciri pokok hubungan

${ }^{36}$ Setyo Widagdo, Op.cit, hal 226 internasional setelah tahun 1945 adalah menjamurnya negara-negara baru setelah membebaskan diri dari kekuasaan kolonial. Akibatnya sekitar 140 Negara baru muncul dalam pergaulan internasional selama waktu tersebut dan semuanya menjadi anggota PBB. ${ }^{37}$ Diterimanya secara langsung negara-negara yang baru lahir pada waktu itu sebagai anggota PBB, dengan jelas menunjukan bahwa teori konstitutif tidak sesuai lagi dengan perkembangan zaman. Persyaratan yang diajukan oleh PBB hanya bahwa negara baru tersebut harus cinta damai (peace loving), menerima kewajiban yang ada dalam piagam, mampu dan bersedia melaksanakan kewajiban dan ditetapkan oleh majelis umum atas rekomendasi Dewan Keamanan PBB. ${ }^{38}$

Persyaratan tersebut, hanya bersifat umum dan tidak pernah menimbulkan permasalahan bagi negara-negara baru. Bagi negara baru, penerimaan sebagai anggota PBB merupakan pengukuhan dari kelahirannya.

Demikian pula dengan kosovo, ketika negara tersebut akan mengajukan permohonan menjadi anggota PBB setelah memenuhi syarat yang ditetapkan dalam piagam PBB maka tidak ada pilihan lain lagi bagi Dewan Keamanan PBB selain memberikan rekomendasi kepada majelis umum untuk menetapkan kosovo sebagai anggota PBB, sekaligus merupakan pengukuhan bagi kosovo sebagai negara baru. Namun demikian, Jika PBB menolak mengakui Kosovo akan tidak

\footnotetext{
${ }^{37}$ Boer Mauna, Op.cit, hal 64

38 Sri Setianingsih Suwardi, Pengantar Hukum Organisasi Internasional, UI Press, Jakarta 2004, hal274
} 
berpengaruh bagi eksistensi Kosovo sebagai negara baru.

\section{Akibat Hukum Pengakuan}

Pengakuan menimbulkan
akibat-akibat atau konsekuensi
hukum yang menyangkut hak-hak,
kekuasaan-kekuasaan dan privilege-
privelege dari negara atau
pemerintah yang diakui baik menurut
hukum internasional maupun
menurut hukum nasional negara
yang memberikan Pengakuan.
Adapun masalah yang harus
diperhatikan apabila masalah
pengakuan timbul karena pengujian,
meskipun sifatnya insindental, oleh
pengadilan-pengadilan Nasional,
dengan persoalan-persoalan
pembuktian dan penafsiran. Dalam
hal ini penting dipertimbangkan
batas-batas antara hukum
internasional dan hukum nasional.
Pengakuan memberikan kepada
negara atau pemeritah yang diakui
suatu status baik menurut hukum
internasional maupun hukum
nasional. ${ }^{39}$ a

Dalam hukum nasional, kemampuan negara atau negara atau pemerintah yang diakui dapat ditinjau dari aspek negatif, yaitu dengan mengemukakan ketidakmampuan kesatuan politik yang disebut negara yang belum diakui. Ketidakmampuan utam dari negara atau pemerintah itu menurut J.G. Starke, ialah sebagai berikut: ${ }^{40}$

1. Kesatuan Politik (baik berupa negara ataupun pemerintah) itu tidak dapat dibawa kedepan pengadilan negara yang tidak mengakuinya. Asas ini termuat

\footnotetext{
${ }^{39}$ J.G. Starke, Op.cit, hal 192

40 Fred Isjwara, Pengantar Hukum Internasional, Alumni, Bandung 1972, hal 76-77
}

dalam diktum keputusan Pengadilan Tinggi New York, dalam perkara "Russian Socialist Federal Soviet Republic Vs Cibrario". Tindakan kesatuan politik yang tidak diakui itu pada umumnya tidak menimbulkan akibat-akibat yang lazim diberikan menurut komitas (kehormatan)

2. Wakil dari negara yang belum diakui tidak dapat menuntut imunitas dalam perkara hukum.

3. Harta milik negara yang tidak diakui dapat dimiliki oleh wakil rezim yang ditumbangkan.

Sedangkan jika dilihat dari aspek positifnya yaitu kemampuan sebagai negara atau pemerintah yang berdaulat penuh yang sudah diakui, ialah sebagai berikut:

1. Berhak perkara di depan pengadilan negara yang mengakuinya

2. Pertimbangan pengadilan negara yang mengakuinya akan dipengaruhi oleh tindakan badan eksekutif dan legislatif yang akan dibentuk oleh pemerintah baru yang bersangkutan

3. berhak akan imunitas dalam perkara mengenai milik dan bagi wakil diplomatiknya

4. Berhak menuntut dan menerima harta milik yang berada dalam yurisdiksi negara yang mengakuinya, milik mana sebelumnya adalah kepunyaan pemerintah yang tumbang.

Dalam Hukum Internasional, kesatuan politik (negara atau pemerintah) yang diakui, menjadi anggota penuhdari masyarakat internasional. Dengan kata lain negara atau pemerintah baru itu dapat menjadi subjek hukum 
internasional, setelah diakui oleh negara lain. Oleh karena itu antara lain ia dapat mengadakan hubungan diplomatik dengan negara yang mengakuinya, dapat menutup atau menandatangani perjanjian internasional dan sebagainya. Dengan demikian Sejak adanya pengakuan dari negara-negara lain, negara atau pemerintah baru yang bersangkutan diwajibkan memenuhi kewajiban internasionalnya.

Dalam sebagian besar kasus mengenai lahirnya negara baru, pengakuan adalah sebagai kebijaksanaan politik negara-negara yang mengakui negara tersebut dan dapat mempunyai akibat:

1. Pengakuan adalah suatu kebijaksanaan individual dan dalam hal ini negara-negara bebas untuk mengakui suatu negara tanpa harus memperhatikan sikap negaranegara lain.

2. Pengakuan adalah suatu discretionary act yaitu suatu negara mengakui negara lain kalau dianggapnya perlu, sebagai contoh;

- Spanyol baru mengakui Peru setelah 75 tahun negara tersebut memproklamasikan kemerdekaanya.

- Belanda baru mengakui Belgia pada tahun 1838 setelah negara tersebut merdeka pada tahun 1831

- Amerika Serikat mengakui Israel hanya beberapa jam setelah negara tersebut lahir tanggal 14 Mei 1948

- Amerika Serikat mengakui RRC sete;lah 30 tahun terbentuknya negara tersebut.

Perlu kiranya dicatat bahwa pengakuan negara hanya dilakukan satu kali. Perubahan bentuk suatu negara tidak akan mengubah statusnya sebagai negara. Perancis misalnya yang dari tahun 1791 sampai tahun 1875 beberapa kali berubah, dari kerajaan, republik, kekaisaran, kembali ke kerajaan dan republik dengan pembentukan Republik III pada tahun 1875, Republik IV tahun 1941, dan semenjak tahun 1958 Republik V tetap merupakan negara Perancis dengan hak-hak dan kewajiban yang sama sebagai subjek hukum internasional dan yang tidak memerlukan lagi pengakuan sebagai negara.

\section{Kesimpulan}

Pengakuan yang merupakan masalah politik dan tidak terlepas juga dari permasalahan hukum, terutama politik internasional namun tidak dapat disangkal bahwa tindakan pengakuan itu berakibat hukum, terutama dalam kaitan hubungan antara pihak yang mengakui dan pihak yang diakui. Selain itu, ada tidaknya pengakuan terhadap negara baru tidak berpengaruh terhadap eksistensi negara baru tersebut, termasuk pengakuan dari PBB.

\section{DAFTAR PUSTAKA}

Boer Mauna, Hukum Internasional, Pengertian Peranan dan Fungsi dalam Era Dinamika Global, Alumni, Bandung 2000

David J.Harris, Cases and Materials on International Law, Sweet and Maxwell, London 1983

Fred Isjwara, Pengantar Hukum Internasional, Bandung 1972 
Gerhard Von Glahn, Law Among Nations, $4^{\text {th }}$. ed. Mac Millan Publishing Inc, New York 1981

I.A. Shearer, Starke's International Law, Butterworth, London 1994

Ian Brownlie, Principles Of Public International Law, $3^{\text {rd }}$.ed., Oxford University Press, New York 1979

J.G. Starke, Pengantar Hukum Internasional, Edisi Kesepuluh, Sinar Grafika, Jakarta 2004

J.L. Brierly, The Law Nations, $5^{\text {th }}$.ed, Clarendon Press, Oxford 1955

Jawahir Thontowi., Pranoto Iskandar., Hukum Internasional Kontemporer, PT. Refika Aditama, Bandung 2006

John O'Brien, International law, Cavendish, London 2001

L. Oppenheim, International Law, A Treaties, $8^{\text {th }}$.ed., Longman, London 1955

Malcom N. Shawn., International Law, $\quad 2^{\text {nd }}$.ed., $\quad$ Grotius Publication Limited, Cambridge 1986

Myres S. Mc. Dongal, W. Michael Reisman, International Law in Contemporary Perspective, The Foundation Press, Inc, Mineola, New York 1981
Nguyen Quoc, Dinh, Patrick Daillier, Alain Peller, Droit International Public, $5^{\text {th }}$.ed, Libraire Generale de Droit et de Jurisprudence, Paris 1994

O'Connel, International Law for Students, Steven \& Sons, London 1971

Setyo Widagdo, Masalah-Masalah Hukum Internasional Publik, Bayu Media Publishing, Malang 2008

Sri Setianingsih Suwardi, Pengantar Hukum Organisasi Internasional, UI Press, Jakarta 2004

Syahmin . A.K., Hukum Internasional Publik dalam Kerangka Studi Analitis 2, Binacipta, Bandung 1992

Tasrif. S., Pengakuan Internasional dalam Teori dan Praktek, PT. Media Raya, Jakarta 1966 Wayan Parthiana, Pengantar Hukum Internasional, Mandar Maju, Bandung 1990

http://www.detiknews.com/read/200 8/09/20/104308/1009385/10/pe lopor-klaim-sepihak-hakkemerdekaan.

http://agguss.wordpress.com/tag/kos ov/

http://www.kapanlagi.com/h/000020 $\underline{4062 . h t m l}$ 